UDC 371.212

DOI: $10.31470 / 2415-3729-2018-8-197-213$

\title{
Formation of the Future Teacher's Professional Competence: European Experience
}

\section{Iryna Prokopenko}

Doctor of Philosophy in Pedagogy (Ph.D), Associate Professor, Head of the Scientific and Methodical

Training Center of Social and Professional Human Development

H. S. Skovoroda Kharkiv National Pedagogical University

$\triangle$ 2, Valentynivska Str., Kharkiv, Ukraine, 61000

E-mail: training.center.hnpu@gmail.com

ORCID: 00000-0001-6554-4461

\section{Формування професійної компетентності майбутнього вчителя: свропейський досвід}

\section{Ірина Андріївна Прокопенко}

кандидат педагогічних наук, доцент, керівник науково-методичного тренінгового центру соціального і професійного розвитку людини

Харківський національний педагогічний університет імені Г. С. Сковороди.

$\checkmark$ вул. Валентинівська, 2, м. Харків, Україна, 61000

Дата надходження статті: 03 серпня 2018 р. Стаття прийнята до друку: 25 листопада 2018 р.

\section{Abstract}

The article clarifies the essence of the concepts of «competence» and «professional competence», determines the components of teacher's professional competence: motivational (interest and motivation for future professional activity), cognitive 
(formed knowledge), operational (acquired skills and abilities) and personal-reflexive (ability to self-esteem, self-development and selfimprovement). The author, on the basis of comparative analysis, shows the experience of forming the future teacher's professional competence in leading countries such as: Germany, Denmark, Great Britain, France and others. The article outlines the peculiarities of the formation of the future teacher's professional competence in determined countries. The interesting aspect in the formation of the future teacher's professional competence in Germany is its information component, whose high level of evaluation is facilitated by the introduction of modern multimedia technologies in the educational process. The peculiarity of the Danish system of the future teachers' professional competence formation is the availability of an additional vocational guidance level. So while forming the professional competence of a future teacher in the UK, considerable attention is paid to student's research activities built on the humanization and democratization of the educational process in this country. The specificity of the future teachers' professional competence formation in universities of France is that its most important component is the information and communication component. On the basis of the conducted analysis, the positive experience of the future teachers' professional competence formation abroad is generalized; the recommendations on its introduction into the system of professional training in higher education institutions of Ukraine are worked out. The conclusion is made that the formation of the future teacher's professional competence abroad will contribute to: the introduction of professional selection of applicants for teaching professions; exploiting the potential of non-formal education; an increase in the duration of teaching practice and the introduction of a mentoring system; inclusion of academic disciplines, that provide inclusive education, into the educational process; providing benefits to active teaching methods based on an interdisciplinary and problem-based approach; creating conditions for the exchange of experience of higher educational institutions with foreign educational institutions.

Key words: professional competence, formation, future teacher, educational process, European countries. 


\section{References}

1. Holotiuk, O. V. (2007). Pidhotovka vchyteliv inozemnykh mov $\mathrm{V}$ universytetakh Frantsii [Preparation of foreign language teachers at the universities of France]. Extended abstract of candidate's thesis. Odessa [in Ukrainian].

2. Zhernovnykova, O. A. (2014). Spetsyfika dydaktychnoi pidhotovky studentiv-matematykiv pedahohichnykh VNZ do roboty $\mathrm{u}$ koledzhakh ta profesiinykh litseiakh [Specificity of didactic training of the math students of pedagogical universities to work in colleges and professional lyceums]. Pedahohika ta psykholohiia - Pedagogy and Psychology, 45, 97-105 [in Ukrainian].

3. Katrevych, L. V. (2016). Profesiina pidhotovka vchyteliv humanitarnykh dystsyplin serednikh shkil v universytetakh Velykoi Brytanii [Professional training of humanities teachers of secondary schools in the universities of Great Britain]. Extended abstract of candidate's thesis. Khmelnytskyi [in Ukrainian].

4. Piankovska, I. V. (2013). Kompetentisnyi pidkhid u fakhovii pidhotovtsi maibutnikh uchyteliv inozemnoi movy u vyshchykh navchalnykh zakladakh Nimechchyny [Competent approach in the professional training of future foreign language teachers in higher education institutions in Germany]. Extended abstract of candidate's thesis. Cherkasy [in Ukrainian].

5. Roliak, A. O. (2011). Profesiina pidhotovka vchyteliv u vyshchykh navchalnykh zakladakh Danii [Teacher training in higher education institutions in Denmark]. Extended abstract of candidate's thesis. Kyiv [in Ukrainian].

6. Anoshkova, T. A. (2015). Implementation of global competency in higher education. Advanced Education, 3, 4-8. DOI: $10.20535 / 2410-8286.43743$.

7. Arnet-Clark, I., Smeets-Cowan, R. \& Kühnis, J. Competences in Teacher Education at Schwyz University of Teacher Education (HHSZ), and the Swiss Education Policy. Pädagogische Hochschule Schwyz, 2015. P. 88-100. Retrieved from http://www. phsz.ch

8. Bhola, H. S. \& Góme, S. V. (2008). Signposts to literacy for sustainable development: complementary studies. Hamburg, Germany: UNESCO Institute for Lifelong Learning. 
9. Mikulecky, L. (1982). Job literacy: the relationship between school preparation and workplace actuality. Reading Research Quarterly, 17 (3), 400-419. DOI: 10.2307/747527.

10. Recommendation of the European parliament and of the council on key competences for lifelong learning. Commission of the European communities, Brussels (2005). Retrieved from http://jows.pl/ sites/default/files/KE_European $\% 20$ Indicator $\% 20$ of $\% 20$ Language $\% 20$ Competence_2005.pdf.

11. Mulder, M., Weigel, T. \& Collins, K. (2007). The concept of competence in the development of vocational education and training in selected EU member states: a critical analysis. Jornal of Vocational Education \& Training, 1, 67-88. DOI: 10.1080/13636820601145630.

\section{Вступ}

Нині процес формування професійної компетентності вчителів розглядається як система неперервної педагогічної освіти, в якій необхідно створювати оптимальні умови розвитку та опанування знань, умінь та навичок у вчителів і реалізації їхнього потенціалу упродовж усього життя. Під професійною компетентністю вчителя розуміється сукупність професійних i особистісних якостей, необхідних для успішної педагогічної діяльності. Професійно компетентним можна назвати вчителя, який на досить високому рівні здійснює педагогічну діяльність, педагогічне спілкування, досягає високих результатів у навчанні та вихованні учнів.

Розвиток професійної компетентності - це формування творчої індивідуальності, формування сприйнятливості до педагогічних інновацій, здібностей адаптуватися до змін в освітньому середовищі. Від професійного рівня педагога безпосередньо залежить соціально-економічний i духовний розвиток суспільства. Поняття професійна компетентність вчителя - це єдність його теоретичної і практичної готовності до здійснення педагогічної діяльності i характеризує його професіоналізм. Під професіоналізмом розуміється особлива здатність особистості, яка готова систематично, ефективно i надійно виконувати професійну діяльність в найрізноманітніших умовах. Компонентами професійної компетентності вчителя є: 
мотиваційний (інтерес та мотивація до майбутньої професійної діяльності), когнітивний (сформовані знання, готовність постійно вчитися і вдосконалювати свою майстерність), операційний (набуті вміння та навички) та рефлексійно-особистісний (здатність до самооцінки, саморозвитку та самовдосконалення) (Жерновникова, 2014; Anoshkova, 2015; Mikulecky,1982; Mulder, M., Weigel, T. \& Collins, K. 2007).

Розв'язанням поставленої проблеми буде ефективним, якщо у своїй статті ми врахуємо не лише український досвід педагогічної освіти, a й із запровадженням позитивного формування професійної компетентності вчителів за кордоном.

Слід зазначити, що основними джерелами для написання статті стали дослідження зарубіжних вчених, аналіз яких дозволив нам узагальнити і систематизувати їх результати і обгрунтувати можливості результативності в підвищенні професійної компетентності вчителя. Ми спираємось на теоретикометодологічні та психолого-педагогічні засади формування професійної компетентності вчителів за кордоном, розкриті дослідниками: Л. Катревич (Велика Британія); І. П'янковська, H. Bhola, S. Gómez (Німеччина); О. Голотюк (Франція), А. Роляк (Данія), I. Arnet-Clark, R. Smeets-Cowan, J. Kühnis (Швеція) та ін.

Мета статті - проаналізувати можливості запровадження європейського досвіду учителів в українську систему вищої педагогічної освіти в контексті формування їхньої професійної компетентності.

\section{Матеріал і методи дослідження}

Для проведення дослідження було використано низку методів наукового пошуку, зокрема - аналіз, синтез, узагальнення та систематизація вітчизняної та зарубіжної наукової літератури.

\section{Результати та їх обговорення}

Процес формування професійної компетентності майбутніх учителів в Україні до професійної діяльності не $є$ ефективним, оскільки повсякчас відбувається реформування системи освіти, змінюються методологічні підходи, розробляються нові норми i принципи навчання. Тому потребує аналізу й узагальнення визначена проблема 3 боку стандартів такої підготовки, вимог до особистості сучасного вчителя, форм і методів 
навчання, організації та проведення педагогічної практики (Жерновникова, 2014). Проведений порівняльний аналіз щодо досвіду формування професійної компетентності майбутнього вчителя в провідних країнах Європи виконано згідно 3 темою наукового дослідження кафедри загальної педагогіки і педагогіки вищої школи Харківського національного педагогічного університету імені Г. С. Сковороди «Підвищення ефективності педагогічного процесу в середніх загальноосвітніх i вищих навчальних закладах» (РК № 0115U005821).

Формування професійної компетентності майбутніх учителів у Франиї. Педагогічна освіта у Франції (Голотюк, 2007) передбачає підготовку вчителя, здатного до свідомої, самостійної та відповідальної суспільної діяльності; опанування ними комунікативними вміннями; наявність професійно важливих для професії вчителя якостей; дотримання морально-етичних норм педагогічної діяльності тощо.

У Франції наявні різні форми дипломів бакалаврату: загальноосвітній, технічний і професійно-технічний, але навіть без наявності бакалаврського диплома можна вступати у ВН3 шляхом складання іспиту на «Диплом доступу до вищої школи» (DAEU), який буває двох видів: A - гуманітарний, В - природничий та інших спеціальностей.

Специфіка підготовки учителів полягає в тому, що така триває чотири роки i дає можливість отримати сертифікат, що надає право викладання. Складання додаткового іспиту «агрегації» - сприяє підвищенню зарплатні вчителя та його кар'єрному просуванню. Зазначимо, що випускники вищих педагогічних шкіл мають не менше 10 років відпрацювати в державному секторі освіти.

Вчителі, як i всі працівники освіти Франції, мають статус державних службовців. Специфіка підготовки майбутніх учителів в університетах Франції зумовлена широким вибором довгострокових i короткострокових програм навчання й отриманням відповідного диплома. Університетам притаманні гнучкий графік занять, розмаїття модулів, навчання 3 повною або частковою зайнятістю, а також наявність вечірніх курсів, стаціонарної та дистанційної освіти. 
Щодо інститутів підготовки вчителів при університетах, то вони забезпечують кадрами дошкільні заклади, початкову та середню школи, старші класи ліцеїв, професійні ліцеї тощо. В таких інститутах готують також заступників директорів iз позакласної роботи, педагогів для розумово відсталих дітей i дітей з фізичними вадами.

Особливості підготовки майбутніх учителів у Франції зумовлені іï відповідністю історичним, політичним і соціальним контекстам; особливостями культурно-національних традицій, поглядів щодо вчителя, його статусу, ролі, професійної компетентності та професійних функцій; сучасними міжнародними педагогічними ідеями: інтеграції, гуманізації, гуманітаризації, професіоналізації, фундаменталізації та глобалізації навчання.

Провідним принципом організації освітнього процесу $€$ принцип взаємодії теорії та практики. Крім того, навчання майбутніх учителів у Франції передбачає створення комфортної атмосфери на заняттях, отримання задоволення від занять, пояснення матеріалу в цікавій і вмотивованій формі, постійний контроль i забезпечення розуміння навчального матеріалу, допомогу студентам, розвиток їх самоповаги. Навчальні заняття спрямовані, крім того, на розкриття майбутніми вчителями особистих талантів і знань, формування зрілих відносин з учнями.

Отже, високий творчий потенціал, глибоке розуміння педагогічних явищ, повага до культур різних країн, володіння фундаментальними соціально-гуманітарними та фаховими знаннями, спроможність до вирішення типових професійних завдань, здатність до навчання й виховання молоді, професійна мобільність, постійне підвищення професійного рівня, здатність до самоусвідомлення, саморозвитку та самовиховання $\epsilon$ підгрунтям формування професійної компетентності.

Формування професійної компетентності майбутніх учителів у Данії. Щодо системи педагогічної освіти в Данії (Роляк, 2011), то базова підготовка майбутніх учителів здійснюється в університетах (академічна освіта) й педагогічних коледжах (загальнопрофесійна освіта). Поєднання академічної та загальнопрофесійної освіти відбувається шляхом уніфікації загальних цілей і програм підготовки вчителів. Системі 
підготовки вчителів у Данії притаманний поступальний розвиток, високий рівень демократичності, стабільність і гнучкість, оскільки особистісно-зорієнтована, дослідницько-зорієнтована й практико-зорієнтована концепції педагогічної освіти відіграють роль механізмів, які логічно поєднують академічну та загальнопрофесійну підструктури в цілісну систему. Спрямовану на формування професійної компетентності.

Підготовка вчителів у Данії здійснюється за базовим (або рівнем бакалавра) та академічним рівнем, що дає змогу здобути ступінь магістра й доктора філософії. Зазначимо, що базовий рівень професійної підготовки майбутні вчителі можуть здобути в коледжах освіти й університетах, тоді як академічний рівень тільки в класичних університетах. Особливістю датської системи підготовки вчителів є наявність додаткового профорієнтаційного рівня, який здобувають у вищих народних школах.

Зміст підготовки майбутніх учителів у Данії визначається освітніми програмами середньострокового (базовий рівень) i довгострокового (академічний рівень) типів. Головними принципами розробки освітніх програм $€$ такі: принцип відповідності змісту педагогічної освіти вимогам суспільства, науки, культури й особистості; єдності теорії та практики; гуманізації й гуманітаризації; фундаменталізації та міждисциплінарності. Навчальні плани підготовки бакалаврів передбачають блоки загальнокультурних, психолого-педагогічних i профільних дисциплін, а також педагогічну практику. Зміст педагогічної практики майбутніх учителів структурується відповідно до змісту загальнокультурних, психолого-педагогічних і профільних дисциплін і передбачає активну та пасивну фази.

Проходження практики дає можливість майбутньому вчителю отримати сертифікат «Про педагогічну практику», що $\epsilon$ обов'язковим додатком до диплома вчителя середньої школи, і без якого вчитель не має права на професійну діяльність у середніх школах Данії. Щодо навчальних програм магістратури, то вони мають науково-дослідницьке та предметне спрямування.

Особливістю змісту підготовки майбутніх учителів у Данії як на базовому, так i на академічному рівні $є$ щільний взаємозв’язок, наступність та інтеграція всіх навчальних програм, 
переорієнтація 3 предметного на компетентнісний підхід, застосування модульного принципу структурування змістових блоків відповідно до європейської кредитно-трансферної системи ECTS. Професійні компетентності вчителя в Данії структуровані на базові, ключові, спеціалізовані та ціннісні. Тому всі блоки дисциплін у навчальних планах мають культурно-історичне та духовне насичення.

Щодо форм і методів підготовки майбутніх учителів у Данії, то така підготовка відбувається відповідно розробленої концепції гуманізації освіти.

Отже, підготовка майбутніх учителів у Данії спрямована, насамперед, на формування професійної компетентності шляхом забезпечення сприятливих умов для всебічного розвитку гармонійної особистості вчителя, його свободи, творчих здібностей, формування готовності до самовдосконалення та самореалізації.

Формування професійної компетентності майбутніх учителів у Німеччині. Підготовка вчителів у Німеччині (П'янковська, 2013; Bhola \& Góme, 2008). підпорядкована єдиним стандартам, які спрямовані на формування ключових i предметних компетентностей вчителів, а також Національній рамці кваліфікацій, що узагальнює вимоги до випускників зі ступенями бакалавра та магістра. Ключові компетентності вчителя стосуються навчання, виховання, оцінювання й інновацій, а предметні - знань і вмінь відповідно до профілю.

Програми підготовки вчителів у кожному університеті та на кожному факультеті в Німеччині розробляють Центри освіти ((П’янковська, 2013; Bhola \& Góme, 2008). Система побудови програм підготовки вчителів $є$ кредитно-модульною: до першого блоку навчальних планів належать обов'язкові курси, які визначають специфіку обраної спеціальності; до другого - елективні курси, що дають змогу на альтернативних засадах обирати одну із обов'язкових дисциплін; до третього дисципліни за вибором.

Отже, можливість вибору студентами змісту навчання $\epsilon$ характерною особливістю підготовки вчителів у Німеччині.

Висока автономія закладів вищої освіти Німеччини не дає змоги виявити єдиний підхід до впровадження компетентнісної 
освіти вчителів. Водночас спільними особливостями підготовки німецьких учителів $є$ такі: функціонування двох моделей підготовки (традиційної та ступеневої) з різним їх співвідношенням на різних землях; розподіл навчання на науково-практичну університетську фазу, що закінчується Першим державним іспитом або здобуттям ступеня бакалавра чи магістра, та педагогічне стажування, що закінчується Другим державним іспитом; незалежно від моделі підготовки навчання майбутніх учителів передбачає опанування двох або трьох предметів, методик їх викладання, педагогічних наук i шкільної практики; період педагогічного стажування (референдаріат) проходить паралельно 3 семінарами, на яких студенти поглиблюють свої теоретичні знання, практичні навички та набувають ключових компетентностей; складання Другого державного іспиту наприкінці педагогічного стажування дає можливість студентам отримати статус державного службовця.

У німецьких закладах вищої освіти домінує інтегративний підхід до формування компетентностей майбутнього вчителя, який передбачає одночасне формування ключових і предметних компетентностей шляхом застосування ігрових технологій в освітньому процесі.

Особливості підготовки вчителів у Німеччині полягають також у тому, що: разом із стажуванням навчання студентів триває 14 семестрів (тоді як в Україні - 10); студентів залучають до

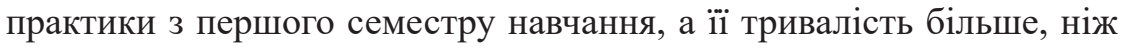
в Україні; німецькі студенти проходять педагогічне стажування за місцем майбутнього працевлаштування, що триває впродовж двох років. Слід зауважити, що в Німеччині існує уніфікована класифікація типів учительських посад, які зумовлюють тривалість підготовки майбутніх учителів і співвідношення іiі складових.

Отже, головними тенденціями підготовки вчителів у Німеччині, які спрямовані на формування професійної компетентності, є такі: європеїзація, орієнтація на міжнародні ініціативи та проекти, мобільність студентів, зростання ролі дослідницької діяльності, широке використання сучасних мультимедійних технологій.

Формування професійної компетентності майбутніх учителів у Великій Британії. Так, у Великій Британії 
(Катревич, 2016) формування професійної компетентності майбутніх учителів відбувається відповідно до прийнятих освітніх стандартів на базі педагогічних коледжів та на базі шкіл School Direct i SCITT.

Сформованість професійної компетентності у майбутніх учителів перевіряють шляхом психологічного тестування придатності до педагогічної діяльності та професійно зорієнтованої співбесіди з приймальною комісією.

Теоретичну підготовку вчителів у Великій Британії здійснюють під час навчання на бакалавраті (передбачає 360 кредитів, 3-4 роки навчання), а практичну - на курсах базової підготовки вчителя PGCE. В Університеті Бірмінгема, наприклад, теоретична підготовка на першому курсі переходить до практично-теоретичної на другому й до самостійно-дослідницької на третьому. Спостерігається тенденція зменшення обсягу обов'язкової та збільшення обсягу варіативної частини навчального плану, що дає змогу студентам обирати дисципліни, спираючись на свої інтереси та кар'єрні потреби. Сформованості професійної компетентності майбутніх учителів сприяє упровадження в освітній процес таких дисциплін, як-от: методика викладання, професійні знання й школознавство, педагогічна практика. Так, курс методики викладання передбачає розвиток професійних умінь i навичок навчання певній дисципліні, адже студенти вчаться планувати уроки й аналізувати їх. Курс професійних знань і школознавства зосереджений на загальношкільній політиці та практиці, професійних і правових обов'язках, відповідальності педагогів. Педагогічна практика триває 24 тижні, й поділяється на кредити, які розкидані на три семестри.

Особливої уваги надається науково-дослідній роботі, оскільки вважається, що професійна компетентність вчителя буде лише тоді сформованою, коли студенти власноруч відшукують факти для обгрунтування своїх ідей, аналізують і презентують їх (проблемне навчання, польове дослідження, ситуаційне навчання, індивідуальні та групові проекти, тьюторське навчання тощо).

Оцінювання знань студентів принципово не відрізняється від України, оскільки здійснюється за допомогою творчих i практичних робіт, дискурсивних есе, курсових робіт, презентацій 
проектів, тестування, усних i письмових іспитів. Водночас найбільш поширеною формою контролю навчальної діяльності британських студентів $\epsilon$ есе, яке передбачає розгорнуту відповідь на поставлене викладачем запитання й потребує його критичного осмислення.

Слід зазначити, що великого значення для підготовки вчителів у Великій Британії набуває так звана неформальна освіта (форма навчання, передбачена загальним планом освітнього процесу, але не регламентована термінами, цілями навчання, оцінкою його якості), оскільки студенти відвідують додаткові навчальні курси на базі центрів підтримки навчальної діяльності студентів, залучаються до волонтерської роботи в школах, беруть участь у освітніх заходах, організованих предметними асоціаціями. Саме неформальна освіта формує в майбутніх учителів формує потребу в неперервному самовдосконаленні та забезпечує тим самим підгрунтя їх подальшого професійного розвитку.

Отже, у Великій Британії домінує послідовна модель підготовки вчителів; вузькопрофільне навчання здійснюється на засадах міждисциплінарного підходу; навчальні плани $є$ чітко скоординованими і гнучкими; перевага надається спеціальним дисциплінам. Що, в свою чергу, у комплексі сприяє формуванню професійної компетентності вчителів.

\section{Висновки}

Проведений аналіз досвіду формування професійної компетентності майбутніх учителів у країнах Європи дає змогу надати пропозиції щодо його використання для вдосконалення системи професійної педагогічної освіти в Україні, зокрема: запровадити професійний відбір абітурієнтів на вчительські професії; використовувати потенціал неформальної освіти; збільшити тривалість педагогічної практики та запровадити систему наставництва; залучати до розробки змісту освітньопрофесійних програм підготовки вчителів досвідчених педагогівноваторів; включити навчальні дисципліни, що забезпечують інклюзивну освіту; надати перевагу активним методам навчання на основі інтегрованих підходів; створити умови для обміну досвідом закладів вищої освіти із закордонними; підпорядкувати систему підготовки майбутніх учителів в Україні світовим та 
європейським стандартам 3 метою визнання вітчизняних або отримання подвійних дипломів.

Перспективи подальших розвідок убачаємо в проведенні порівняльного аналізу щодо упровадження ефективних інноваційних форм, методів та засобів навчання майбутніх учителів, які спрямовані на формування їхньої професійної компетентності.

\section{Література}

1. Голотюк О. В. Підготовка вчителів іноземних мов в університетах Франції : автореф. дис. ... канд. пед. наук : 13.00.04. Одеса, 2007. 20 с.

2. Жерновникова О. А. Специфіка дидактичної підготовки студентів-математиків педагогічних ВНЗ до роботи у коледжах та професійних ліцеях. Педагогіка та психологія : зб. наук. праць. Х. : ТОВ «Щедра садиба плюс», 2014. Вип. 45. С. 97-105.

3. Катревич Л. В. Професійна підготовка вчителів гуманітарних дисциплін середніх шкіл в університетах Великої Британії : автореф. дис. ... канд. пед. наук : 13.00.04. Хмельницький, 2016. 20 с.

4. П’янковська I. В. Компетентісний підхід у фаховій підготовці майбутніх учителів іноземної мови у вищих навчальних закладах Німеччини: автореф. дис. ... канд. пед. наук : 13.00.04. Черкаси, 2013. 20 с.

5. Роляк А. О. Професійна підготовка вчителів у вищих навчальних закладах Данії : автореф. дис. ... канд. пед. наук : 13.00.04. Київ, 2011. 20 с.

6. Anoshkova T. A. Implementation of global competency in higher education. Advanced Education, 2015. Vol. 3. P. 4-8. http:// dx.doi.org/10.20535/2410-8286.43743

7. Arnet-Clark I., Smeets-Cowan R. \& Kühnis J. Competences in Teacher Education at Schwyz University of Teacher Education (HHSZ), and the Swiss Education Policy. Pädagogische Hochschule Schwyz, 2015. P. 88-100. URL: http://www.phsz.ch

8. Bhola H. S., Gómez S. V. Signposts to literacy for sustainable development: complementary studies. Hamburg, Germany: UNESCO Institute for Lifelong Learning, 2008. 
9. Mikulecky L. Job literacy: the relationship between school preparation and workplace actuality. Reading Research Quarterly, 1982. Vol. 17 (3). P. 400-419. https://doi.org/10.2307/747527.

10. Recommendation of the European parliament and of the council on key competences for lifelong learning. Commission of the European communities, Brussels. Retrieved from, 2005. URL: http://jows.pl/sites/default/files/KE_European\%20Indicator\%20of $\% 20$ Language $\% 20$ Competence_2005.pdf

11. Mulder M., Weigel T. \& Collins K. The concept of competence in the development of vocational education and training in selected EU member states: a critical analysis. Jornal of Vocational Education \& Training, 2007. Vol. 1. P. 67-88. https://doi. org/10.1080/13636820601145630.

\section{Прокопенко I. A.}

\section{Формування професійної компетентності майбутнього вчителя: свропейський досвід}

\section{Анотація}

В статті 3'ясовано суть понять «компетентність» та «професійна компетентність», визначено компоненти професійної компетентності вчителя: мотиваційний (інтерес та мотивація до майбутньої професійної діяльності), когнітивний (сформовані знання), операційний (набуті вміння та навички) та рефлексійно-особистісний (здатність до самооцінки, саморозвитку та самовдосконалення). Автором, на основі порівняльного аналізу, показано досвід формування професійної компетентності майбутнього вчителя в провідних країнах, таких як-от: Німеччина, Данія, Велика Британія, Франція тощо. В статті виокремлено особливості формування професійної компетентності майбутнього вчителя у визначених країнах. Цікавим при формуванні професійної компетентності майбутнього вчителя в Німеччині є iі інформаційна складова, високому рівню оцінювання якої сприяють упровадження в освітній процес сучасних мультимедійних технологій. Особливістю датської 
системи формування професійної компетентності майбутніх учителів $є$ наявність додаткового профорієнтаційного рівня. Так при формуванні професійної компетентності майбутнього вчителя у Великій Британії значна увага приділяється дослідницькій діяльності студента, побудованій на гуманізації та демократизації освітнього процесу в цій країні. Специфіка формування професійної компетентності майбутніх учителів в університетах Франції у тому, що найважливішою іiі складовою $€$ інформаційно-комунікаційна складова. На основі проведеного аналізу узагальнено позитивний досвід формування професійної компетентності майбутніх учителів за кордоном, розроблено рекомендації щодо його впровадження в систему професійної підготовки в закладах вищої освіти Україні. Зроблено висновок, формуванню професійної компетентності майбутнього вчителя за кордоном сприятиме: запровадження професійного відбору абітурієнтів на вчительські професії; використання потенціалу неформальної освіти; збільшення тривалості педагогічної практики та запровадження системи наставництва; включення в освітній процес навчальних дисциплін, що забезпечують інклюзивну освіту; надання переваг активним методам навчання на основі міждисциплінарного та проблемного підходів; створення умов для обміну досвідом закладів вищої освіти із закордонними освітніми закладами.

Ключові слова: професійна компетентність, формування, майбутній учитель, освітній процес, європейські країни.

\section{Прокопенко И. А.}

\section{Формирование профессиональной компетентности будущего учителя: европейский опыт}

\section{Аннотация}

В статье выявлена сущность понятий «компетентность» и «профессиональная компетентность», определены компоненты профессиональной компетентности учителя: мотивационный (интерес и мотивация к будущей профессиональной 
деятельности), когнитивный (сформированные знания), операционный (приобретенные умения и навыки) и рефлексивныхличностный (способность к самооценке, саморазвитию и самосовершенствованию). Автором, на основе сравнительного анализа, показано опыт формирования профессиональной компетентности будущего учителя в ведущих странах, таких как: Германия, Дания, Великобритания, Франция и др. В статье выделены особенности формирования профессиональной компетентности будущего учителя в определенных странах. Интересным при формировании профессиональной компетентности будущего учителя в Германии является ее информационная составляющая, высоком уровню оценки которой способствуют внедрению в образовательный процесс современных мультимедийных технологий. Особенностью датской системы формирования профессиональной компетентности будущих учителей является наличие дополнительного профориентационного уровня. Так при формировании профессиональной компетентности будущего учителя в Великобритании значительное внимание уделяется исследовательской деятельности студента, построенной на гуманизации и демократизации образовательного процесса в этой стране. Специфика формирования профессиональной компетентности будущих учителей в университетах Франции в том, что важнейшей ее составляющей является информационнокоммуникационная составляющая. На основе проведенного анализа обобщенно положительный опыт формирования профессиональной компетентности будущих учителей за рубежом, разработаны рекомендации по его внедрению в систему профессиональной подготовки в учреждениях высшего образования Украины. Сделан вывод, формированию профессиональной компетентности будущего учителя за рубежом будет способствовать: введение профессионального отбора абитуриентов на учительские профессии; использования потенциала неформального образования; увеличение продолжительности педагогической практики и внедрение системы наставничества; включение в образовательный процесс учебных дисциплин, обеспечивающих инклюзивное образование; предоставление преимуществ активным методам обучения на 
основе междисциплинарного и проблемного подходов; создание условий для обмена опытом высших учебных заведений с зарубежными образовательными учреждениями.

Ключевые слова: профессиональная компетентность, формирование, будущий учитель, образовательный процесс, европейские страны. 